\title{
AN EMPERICAL STUDY ON ORGANIC FARMING PRODUCTS AT ORGANIC TUMAKURU - A STUDY WITH SPECIAL REFERENCE TO TUMAKURU DISTRICT
}

\author{
Dr. R. SHASHI KUMAR ${ }^{1}$, BHAGYAMMA.N ${ }^{2}$ \\ ${ }^{1}$ Professor, Department of Economics, Bangalore University, Bangalore-560056. \\ ${ }^{2}$ Research scholar, Department of Economics, Bangalore University, Bangalore-560056.
}

\begin{abstract}
Farming is a very old and a well-known traditional occupation in India. The farming which is said to be done with a very healthy note in olden days is now not addressed the same. There is a growing importance on health benefits as people are becoming conscious about the food they and their family members consume. Through the concept is not new to us. We are seeing a rise in organic farming, as it is the need of all of us. Consumers are becoming highly conscious about their health and the foods they consume more and more people are opting for organic food to avoid the consumption of foods to avoid that are grown using chemical preservatives. India is bestowed with lot of potential to produce all varieties of organic products due to its agro-climatic regions. In several parts of the country, the inherited tradition of organic farming is an added advantage. The study reveals that there is significant demand for organically grown producer. Hence, more retail outlets can be established, which results validates in self-employment and sustainable nature of farming that can be promoted. Organic farming systems have attracted increasing attention over the last one decade, because they are perceived to offer some solutions to the problems currently besetting the agricultural sector. Organic farming has the potential to provide benefits in terms of environment protection, conservation of non-renewable resources and improved food quality. Organic farming continues to be developed by various organic agriculture organizations today. It relies on fertilizers of organic origin such as compost manure, green manure, and bone meal and places emphasis on techniques such as crop rotation and companion planting. Biological pest control, mixed cropping and fostering of insect predators are encouraged.
\end{abstract}

Key Words: Marketing, Organic Farming, Self employment, Sustainable Development Retail Stores.

\section{INTRODUCTION}

Organic farming has the potential to provide benefits in terms of environmental protection, conservation of nonrenewable resource and improved food quality. India is bestowed with lot of potential to produce all verities of organic products due to its diverse agro climatic regions. Increasing awareness towards health and environmental issues associated with the intensive use of chemical inputs has let to alternative forms of agriculture organic farming continues to be developed by various Organic Agriculture Organizations today. The India is agriculture dominating country, where more than 75 percent population directly or indirectly depends upon agriculture. Due to continuous growth of population the requirement of food and other agriculture material is increasing day-by-day. Since the expansion of geographical and agriculture land of country is impossible, hence, the population pressure is increasing on agriculture sector. To overcome the above pressure farmers had started to take the help of chemicals the problems like losses in land productivity, imbalance availability of nutrients, food poisoning, environmental pollution, water and air pollution and gene erosion have been created. But in that time the information regarding the ill effect of these chemicals was not well known. Due to this reason there are challenges before the agriculture scientists in present time to develop sustainable agriculture plan to escape these ill effects. It relies on fertilizers of organic origin such as composed manner, green manure and bone meal and places emphasis on techniques such as crop rotation and companion planting, Biological pest control mixed cropping and the fostering of insect predators are encouraged. Organic agriculture can be defined as: An integrated farming system that strives for sustainability the enhancement of soil fertility and biological diversity while with rare expectations, prohibiting synthetic pesticides, antibiotics, synthetic fertilizers, genetically modified organisms, and growth hormones. The sustainable agriculture is successful management of local terrestrial resources with aim to satisfy the change in human need and improving or maintaining the environmental quality without degradation of our nature base. The later implies a farming system that primarily aims at cultivating land and raising crops under ecologically favourable condition. 


\section{International Advanced Research Journal in Science, Engineering and Technology}

Vol. 8, Issue 10, October 2021

\section{DOI: 10.17148/IARJSET.2021.81027}

\section{OBJECTIVES}

1. To support the farmers for value addition for agricultural produce.

2. Create awareness about the organic farming.

3. Understand low cost production of organic farming by using less resource.

4. To develop market linkages with whole sale traders, companies, production units and avoid the middlemen interference.

5. To provide inputs and services related to agriculture

6. To train the farmers on improved agriculture technologies and practices.

\section{SCOPE OF THE STUDY}

Organically grown products are rich market. India is agriculturally dependent country, which constitute of large number of farmers with small holds of land. These farmers are contributing less agriculture produce to the market, resulting in loses. If these farmer practice organic farming in agriculture they can save the fertility of the land resulting in high yield once the period of time and contribute to the increase in market share of organic produce globally organic agriculture should sustain and enhance the health of soil, plant, animal and human as one and individual.

\section{METHODOLOGY}

The methodology of this study is empirical in nature. A primary study was conducted at "Organic Tumakuru Farmers Federation" A structured interview schedule was designed and focused interview was conducted in order to get the data from the concerned group finally the results are drawn based on the analysis and interpretation of the data collected. Based on the possible outcomes the results are drawn.

\section{LIMITATIONS OF THE STUDIES}

The following are important limitation of our research work.

1. The study is conducted only at the Organic Tumakuru retail outlet and the interviewed only few respondents.

2. The study is not focused to a large population.

3. The period of the study is limited.

\section{THE MAIN PRINCIPLE OF ORGANIC FARMING}

- $\quad$ To maintain the long term fertility of soil.

- To avoid all forms of pollution that may results from agricultural techniques.

- $\quad$ To reduce the use of fossil energy in agricultural practice to a minimum.

- $\quad$ To produce foodstuffs of high nutritional quality and sufficient quantity.

- $\quad$ To make it possible for agricultural producers to earn living through their work and develop their potentialities as a human being.

\section{FINDINGS OF THE ORGANIC FARMING}

In the Tumakuru district the main cropping season Kharif, ragi and ground nut are the main crops which occupy about $70 \%$ of the cultivable area. Followed by paddy, maize, and red gram. The total normal Kharif area under agricultural crops in is 4.80lakh hectares around 0.10lakh hectares is covered during Rabi and 0.15lakh hectares during summer season. The production is over and above the requirements of the district with regard to cereals (3.87lakh tones). But Tumakuru falls behind in meeting the requirement of pulses and oil seeds 0.306 and 1,06lakh tonnes respectively.

Under the Government of Karnataka, 15 organizations are registered as Organic Federations. The Tumakuru District Regional Co-operation Organic Farmers Organization federation is one among the Registered Federation. Tumakuru District Regional Co-operation Organic Farmers Organizations Federation Limited is one among 15 Regional Federations formed by Department of Agriculture, Government of Karnataka to promote Organic Farming and to avoid middle men in trading in December 2015. The Federations has 42 organic clusters with 4099 farmers of which 983 are women farmers covering an area of 10071 acres. The federation is into wholesale and retail business of raw and processed organic produce of these clusters since the middle of 2016. 


\title{
International Advanced Research Journal in Science, Engineering and Technology
}

\author{
Vol. 8, Issue 10, October 2021
}

\section{DOI: 10.17148/IARJSET.2021.81027}

The more crops produced in the organic clusters are coconut, peanuts, finger millet, foxtail millet, brown top millet, kodo, millet, little millet, pearls millet, sorghum millet, prosco millet, barnyard, pulses like green gram, red gram, hose gram, niger seed, mustards, banana, tarmarind, mango, jackfruit, etc. The federation has a setup for cleaning grading of pulses and cleaning, grading of millets. The federation manufactures some value added products like, virgin coconut oil, millet flour, millet biscuits, and few snacks made out of millets.

Tumakuru Regional Co-operative Organic Farmers Association Federation Limited registered during 2015-16. These federations took up collection, grading, value addition, processing, packing, brand development and marketing of organic produce, apart from creating consumer awareness programme and other activities.

In this study discussion based on experience gained in practice and encompasses the some benefits.

a) Organic farming is sustainable and diverse.

b) Organic farmers conserve resources.

c) Organic products provide market access and added value.

Marketing of organically grown products are the key, so it needs to cover all areas from short chain marketing such as local farmer markets and local shops, direct to consumers such as Community-Supported Agriculture, regional markets with Participatory Guarantee Systems (PGS) to national and international trade using third party certification systems.

\section{LOW COST FARMING}

By practicing conventional farming methodologies today's farmer is in deep crises. He is not able to get suitable market price for his agricultural produce farming switching over to organic method of farming, can make use of less resource and produce better yield over a period. India's rank in terms of world's organic agricultural land was $15 \%$ as per 2013 data. The total area under organic certification is 5.71 million hectare (2015-16). Certified and in conversion area and products of Tumakuru district 2017-18. In Tumakuru District the area of organic farming (hectare) is 409.44 and in conversion area is 2568.26. Hence, the total area of Organic Farming is 2977.70 hectare.

Tumakuru Regional Co-operative organic Farmers Association Federation Limited took up collection, grading, value addition, processing, packing, brand development and marketing of organic produce a part from creating consumer awareness programme and other activities.

The major crops in Tumakuru Districts are ragi, minor, millets, groundnut and vegetables. The number of member organizations of organic farming is 42, number of farmers 4099, certified organic area is 10071 acres in 2016-2017.

Organic Farming villages under the Savayava Bhagya Yojana of Tumakuru District.

\begin{tabular}{|l|l|l|l|}
\hline S1 no. & Taluku Name & Organic Area (ha) & In Conversion Area (ha) \\
\hline 1 & Tumakuru & 605 & 134 \\
\hline 2 & Turuvekere & 307 & 284 \\
\hline 3 & Tipaturu & 218 & 241 \\
\hline 4 & Sira & 414 & 427 \\
\hline 5 & Chikkanayakanahalli & 409 & 465 \\
\hline 6 & Gubbi & 501 & 523 \\
\hline 7 & Koratagere & 297 & 354 \\
\hline 8 & Kunigal & 500 & 573 \\
\hline 9 & Madhugiri & 508 & 381 \\
\hline 10 & Pavagada & 301 & 251 \\
\hline
\end{tabular}

Source: Organic Farming Directory of Karnataka, Dr.N. Devakumar and B.P. Amarnath. Karnataka State Department of Agriculture and University of Agricultural Sciences, Bangalore.

Organic Products market in Tumakuru District.

\begin{tabular}{|l|l|l|l|l|}
\hline S1 No. & Name Turnnover & Market Turnover 2017 & $\begin{array}{l}\text { Market } \\
\text { Lingetes }\end{array}$ \\
\hline 1 & $\begin{array}{l}\text { Tumakuru Regional Co- } \\
\text { operative Organic Farmers } \\
\text { Association Federation } \\
\text { Limited }\end{array}$ & & 80 Lakh & $\begin{array}{l}\text { Phalada } \\
\text { Organics and } \\
\text { Arogya } \\
\text { Organics }\end{array}$ \\
\hline
\end{tabular}

Source: Department of Agriculture, Government of Karnataka 


\section{International Advanced Research Journal in Science, Engineering and Technology}

Vol. 8, Issue 10, October 2021

\section{DOI: 10.17148/IARJSET.2021.81027}

\section{GOVERNMENT SUPPORT}

The Government of India is promoting Organic Farming through various schemes like,

- $\quad$ National Project on Organic Farming (NPOF).

- $\quad$ National Horticulture Mission (NHM).

- $\quad$ Horticulture Mission for North East and Himalayan States (HMNEH).

- $\quad$ National project on Management of Soil Health and Fertilizer (NPMSHF).

- $\quad$ Rashtriya Krishi Vikas Yojana (RKVY).

- $\quad$ Network Project on Organic Farming of Indian Council of Agriculture Research (ICAR).

1) National Project on Organic Farming.

Under National Project on Organic Farming (NPOF) scheme, assistance up to 25percent and 33percent of financial outlay up to a ceiling of Rs.40lakhs and Rs. 60lakhs respectively is provided as back ended subsidy through NABARD for establishment of bio- pesticides, fertilizers production units and agro waste compost production units respectively.

2) National Horticulture Mission.

Under the National Horticulture Mission and Horticulture Mission for North East and Himalayan States, financial assistance is provided for setting up vermi- compost production units at 50 percent of the cost subject to a maximum of Rs. 30,000 per beneficiary, for adoption of organic farming at Rs. 10,000 per hectare for maximum area of 4 hectare per beneficiary and for organic farming certification at Rs, 5.00lakh for a group of farmers covering an area of 50 hectares.

3) Rashtriya Krishi Vikas Yojana

Assistance for promotion of organic farming on different components are also available under Rashtriya Krishi Vikas Yojana (RKVY) with the approval of State Level Sanctioning Committee.

4) National Food Security Mission

Under National Food Security Mission (NFSM) on Pulses, including Accelerated Pulses Production Programme (A3P), assistance for popularizing Rhizobium culture/Phosphate Solubilizing bacteria is provided to the farmers under cluster demonstrations.

\section{REVIEW OF LITERATURE}

Regi Thames, ${ }^{1}$ (1993) From his case study found that transition from conventional to ecological agriculture yielded more. In the first year, the result was poor, yields were still less. The second year onwards, yields and soil began to improve, by the third year, yield started showing significant improvement. Coconut yielded 240 percent increase along with the increased yield of 480 percent from inter crop. In rubber, the yield came down by 20percent, but when compared with the profit, it was remaining the same. He also concluded in his research that the alternative ecological practices were found to be superior to conventional agriculture.

Das K., Meachlhi. D.N. and Guha B, ${ }^{2}$ (2001) Recycling effect of crop resiuse with chemical fertilizers on physico chemical properties of soil and rice yield India Journal of Agronomy. He studies the effect of soil on rice of crop residues.

Ramesh.P, ${ }^{3}$ (2005) In this study the organic farming, It relevance to the Indian context, present study considering the potential environmental benefits of organic production and its compatibility with integrated agricultural approaches to rural development, organic farming may be considered as a developed vehicle for developing countries like India in practical.

Thapa V., and Tripathy $\mathrm{P}^{4}$ (2005) Organic farming in India problem and prospects, this in the concept, merit ,demerit, inputs and methods of organic farming as compost, organic manures, bio-fertilizers effective micro- organism, technology, crop residue and meet management, pest management. The explanation of cost involved in yield level and labor utilization between organic farming and conventional farming.

Ramesh P. Singh Mohan and Rao Subha, ${ }^{5}$ (2005) Organic Farming, It relevance to the India context, present paper considering the potential environmental approaches to rural development, Organic Agriculture may be considering as a developed vehicle for developing countries like India in practical. 


\title{
International Advanced Research Journal in Science, Engineering and Technology
}

\author{
Vol. 8, Issue 10, October 2021
}

\section{DOI: $10.17148 /$ IARJSET.2021.81027}

Sharma, ${ }^{6}$ (2001) reported that the term "Organic farming" was used by lord northborn in the book "Look at the land" North born had a vistion of the farm as a sustainable, ecologically, stable, self contained unit, biologically complete and balanced living. The term thus did not refer safely to the use of living materials like organic manures in agriculture.

Hectmam, ${ }^{7}$ (2007) professor in the plant Biology and Pathology department at Rutgers University reported the recent rapid growth of the organic movement had resulted in a loss of connection with the historical figures and roots of organic agriculture. He further added that Sir Albert Howard (1873-1947) who was regarded by most of the founder.

Kannan V.C., ${ }^{8}$ (2009) converted his six acre farm to 'fully organic' some years ago. Three acres are for sugarcane, one acre for paddy and two acres have a mixture of bananans, vegetables, turmeric, etc. and also he learnt of the negative effects of chemical farming and how it degrades the soil.

Reeta Ganapathy, ${ }^{9}$ (2009) has a five acre plot of farmland and has become organic farmer since the past ten years. Earlier she was used chemical fertilizers and with it one naturally had to also use pesticides and so on. She also realized that chemical farming spoils the soil which is why more and more chemicals are needed each year to give the same results and this is what makes chemical farming so costly.

Anil Agarwal, ${ }^{10}$ (1993) stated that in Tamil Nadu some Municipal Corporations have began to sell organic manure to tanners which will not only solve the problem of waste disposal, but also supplement their budgets. He cited the case of Thanjavur Municipal Corporation which sold 14.790 tonnes of organic manure for Rs.1,69lakhs in 1992-93. The manure consisted largely of wastes from slaughter houses and vegetable markets, besides domestic wastes.

\section{CONCLUSION}

India depends on agriculture and if the production which can be done through the benefits of the organic cultivation there would be not only good output of the crops but also would be leading to the nutritious foods, when the organic products are promoted in large scale it creates more of self employment for the younger generation, organic farming is one of the ways that can contribute for the make in India success. The success can be provided by offering the health, ecological sustainability, scope for entrepreneurial ventures, export of organic products and promoting tertiary sector of our nation. This is the main result of the use of the organic inputs in the production. Thus, involvement of the state, central, agricultural department is necessary for rapid of organic farming in the country with the support of the state and central government.

\section{REFERENCES}

1. Regi Thames,(1993)- "National Agriculture Policy Impact Analysis and Policy Options For Sustainable Agriculture", M.Phil (Futurology) Dissertation (Unpublished). Gandhigram Rural University, Gandhigram, Dindigul, Tamilnadu, India.

2. Das K., Meachlhi. D.N. and Guha B(2001)-Pesticides: Their Ecological Impact in Developing Countries, Commonwealth Publishers, New Dehli

3. Ramesh.P(2005)- "Food security depends on small and marginal dry land farmers" The Hindu, $6^{\text {th }}$ May 2005.

4. Thapa V., and Tripathi P (2005)- Indian Farmers experience and perceptions of organic farming, Renewable Agriculture and Food Systems,27(2),pp.157-169.

5. Ramesh P. Sing Mohan and Rao Subha Organic Farming: It relevance to the Indian context (2005)

6. Sharma "Plant protection practice in organic farming international book distributors, New Delhi PP, 24-26.

7. Hectmam (2007), Theortical frame work to promote organic produce marketing in India, Indian Journal of Agiculture marketing conference number special PP-1-16.

8. Kannan (1995), “Organically grown Basrnati Rice", the Hindu, May 31.

9. Reeta ganapathi 2009, Illuppakkorai, Ganapathiagraharam, Via, papanasam Taluka, Tanjore, District, Tamilnadu, organic farmers association of Indian Survey, Organic farmers in Tamil Nadu.

10. Introduction Karnataka Organic Farming Policy Bhaskar save, Bhaskar save, $29^{\text {th }}$ July 2006, introduction; Karnataka organic farming policy and project.

11. Kulkarni, S (2016) January 31, India needs to be a low cost hub for make in India success, Deccan Herald.

12. Dhaliwal, GS and Singh,B (eds.),1993, Pesticides: Their Ecological Impact in Developing Countries, Commonwealth Publishers, New Delhi.

13. Government of India, Ministry of Commerce and Industry, 2000, National Programme for Organic Production Containing the Standards for the Organic Products, Cochin.

14. Balaji, V. and Lathanagarazan,M.S.1994, Agriculture ecological rice farming for energy efficiency. The Hindu, $24^{\text {th }}$ August.

15. Berzsenyi z, Gyorffy B, Lap D (2000) Effect of crop rotation and fertilization on maize and wheat yields and yield stability in a long term experiment . Eur J Agr13(2-3); 225-244.

16. Bhattacharya p, D(2003) Current status of regulatory mechanism in organic farming fertilizer News 49 (11); $33-38$ 